\title{
Democracy and Islam in Malek Bennabi's Thought
}

\author{
Yahia H. Zoubir
}

The growth of political Islam in the 1970 s and the possibility of Islamist parties coming to power in various countries led many scholars and political analysts to question the compatibility of Islam and democracy. Most studies have concentrated on popular Muslim thinkers who were considered Islamic activists such as Sayyid Qutb or Abu 'Ala AlMaududi, but no attention has been paid to the thought of the remarkable Algerian Islamic thinker, Malek Bennabi (1905-1973). A French-educated electrical engineer, strongly influenced by the ideas of Rashid Rida and Mohammed Abdu, Bennabi's most important concern throughout his life was the adaptation of Islamic values to modernity. Very familiar with western civilization - as well as many others - he felt that the Muslim world failed to rise above its inertia not only because it is incapable of absorbing modern technology, but also because its elite borrowed failing ideologies, such as Marxism, without attempting to recapture the best values that were produced by Islamic civilization. In other words, the Muslim world failed to reproduce the experience of such successful nations as Japan. In his view, Japan achieved modernity because "the 'deadly ideas' [i.e., materialism] of the west did not make it deviate from its path: It [Japan] remained faithful to its culture, its traditions, and its past."1 More importantly, throughout his work Bennabi puts most of the blame for the Muslim world's predicament, not on western colonialism, but on the Islamic world itself, a notion that runs against the prevailing opinion in the Arab-lslamic world that argues that western powers are mostly responsible for the backwardness of the Muslim world.

After his return to Algeria in 1963, following his long exile in Egypt, Malek Bennabi joined the first Islamist organization in Algeria, Al-Qiyam al-Islamyya (Islamic Values), founded the same year. The association was opposed to the "Marxist" policies of President Ahmed

Yahia H. Zoubir is an Associate Professor of International Studies at Thunderbird, the American Graduate School of International Management in Arizona. 
Ben Bella's and Houari Boumediene's regimes. Although many important religious authorities were members of the association, Bennabi, a maverick, was the most prominent. Yet owing to his unique and critical views, it is not determined how much imprint he had on the direction of Al-Qiyam, whose primary concerns revolved around issues of morality. What is certain, however, is that Bennabi had a powerful influence upon the early, French-educated Islamists who attended the University of Algiers in the 1960 s and early 1970 s (i.e., until his death in 1973). ${ }^{2}$ When Bennabi expressed his ideas about Islam in a review written in the French, he said, "Que sais-je de l Islam?" (What do I know about Islam?). Islam's popularity went well beyond the premises of the University of Algiers, on whose grounds the mosque founded in 1968 attracted the most educated Islamists, especially physical scientists. ${ }^{3}$ Malek Bennabi's views can best be described as gradualist and even intellectualist, which is perhaps the main reason why they have aroused little interest among the more radical Islamists. Further, Bennabi's thinking on the relationship between Islam and democracy - which he articulated in the $1940 \mathrm{~s}$ - was not known until the publication of the booklet, La democratic en Islam, in the late 1980s.

Malek Bennabi's thinking, which was little known even in Algeria, has had no influence whatsoever on the Islamist movement. The ideas of this extraordinary philosopher on the compatibility of Islam and democracy proves that he was an Islamic thinker rather than an Islamist concerned with the seizure of power; Bennabi's preoccupation was of a different nature than the immediate socioeconomic and political considerations of the Islamists in the 1980s and 1990s.

Bennabi lived in a more prosperous Algeria than the Algeria of today. Even though he was critical of some of President Houari Boumediene's policies, his writings suggest that he did not disagree with him on a number of important questions, especially those related to broad third world issues. Bennabi rejected what he called "economism," which he saw as an obsessive concern throughout the Muslim world with technological progress at the expense of civilizational (i.e., cultural) values. Although he was clearly anti-Marxist, he was not against socialist ideas as such. He abhorred materialism but appreciated the concern for social justice. Bennabi was convinced that neither Gamal Abdul-Nasser's nor Boumediene's policies had any chance of succeeding unless Islam and Islamic values were integrated as guiding principles. ${ }^{4}$

\section{Democracy in Islam}

Bennabi's writings on the relationship between Islam and democracy is the least known of his works. Yet, it is one of the most interesting, for his approach to democracy discloses the incredible level of culture this 
Islamic thinker possessed. His penetrating understanding of Islam, on the one hand, and of western concepts and values, on the other hand, helped him deal with the question of democracy without any complex or a priori prejudice, contrary to some of today's Islamists who regard democracy merely as a western, and therefore alien, import.

Bennabi scrutinizes the concept of democracy from the following three standpoints:

- as a feeling toward one's self,

- as a feeling toward others, and

- as a cluster of social and political conditions necessary for the formulation and the blossoming of similar feelings in the individual. ${ }^{5}$

For him, democracy is the result of a humanistic cultural development. $\mathrm{He}$ argues that democracy is not the simple transfer of power to the masses or to a sovereign people by virtue of a body of laws. It is the maturation of attitudes, reflexes, and principles that produce the essence of democracy in the consciousness of a people and its customs, ${ }^{6}$ that is, what contemporary theorists of democracy today define as elements of "civility."7 In other words, a process of democratization must take place before a democratic constitution can be written. According to Bennabi, one of the preconditions of the democratization process is the eradication of antidemocratic feelings and despotic tendencies. ${ }^{8}$

The problem posited by Malek Bennabi is, Can Islam foster the three perspectives raised above? In other words, Can Islam augment the sentiment toward one's self and toward others, one that is compatible with the foundation of democracy within the individual's psychology, and can it create social conditions that are favorable to the preservation and development of the democratic sentiment as well as its efficaciousness? ${ }^{9} \mathrm{He}$ repudiates any democratic endeavor that consists of appropriating certain principles from foreign democratic constitutions without actions taken to inculcate them in the psychology of the people that adopt them. ${ }^{10}$ Bennabi's observations cause him to deduce that "if there exists a democratic tradition in Islam, it ought not to be sought in the letter of a constitutional text, but rather in the spirit of Islam in general."11 Islam must, therefore, be thought of as the initiation of a process of democratization, that is, the progression of the individual and the society to which he belongs toward the democratic ideal. ${ }^{12}$ According to Bennabi, the difference between the Islamic democratic concept and either the French, Russian, or Chinese democratic concepts is that Islam endows man with a significance that transcends any political or social value. While other democratic definitions detect in man the presence of humanity and society, the Islamic democratic conception recognizes in man the presence of God. In other words, the first definition of democracy is of the secular type, while the second is of the sacred kind. ${ }^{13}$ 
In Bennabi's conception, individuals who carry the honor of God within themselves sense that privilege, not only within themselves, but within others as well. This is sufficient to offset any negative sentiments human beings may have toward themselves or toward others. Moreover, God has provided Muslims with safeguards that protect them against enslavement and against developing despotic inclinations. It is noteworthy that Bennabi quotes a verse from the Qur'an which exhorts a Muslim to leave the country rather than succumb to slavery ${ }^{14}$ or to take up arms against the oppressor.

Clearly, in this analysis Islamic democracy is characterized essentially by the humans' immunization against antidemocratic attitudes: The bestowing of political rights and social guarantees evolve from this assessment. Bennabi argues that, contrary to Islamic democracy, secular democracy confers upon humans guarantees and rights but does not provide them with safeguards against the power of cartels and trusts or against the dictatorship of a class. In other words, secular democracy does not cleanse society of the evils that produce servitude or tyranny. ${ }^{15}$

Bennabi's conception of democracy extends beyond the political sphere. For him, the social dimension of democracy is very important, for "an order which bestows upon man a ballot and lets him die is not a democratic order." 16 Bennabi then proceeds to make evident the respect of individual freedoms in Islam. In opposition to many of today's Islamists, Bennabi quotes from the Qur'an the verses that come closest to today's individual freedoms, such as the right to work and to travel. He contends that freedom of speech is guaranteed in Islam and that the Prophet Muhammad himself urged his companions to evaluate his decisions. ${ }^{17}$ The privacy of the home, he asserts, is also guaranteed by the verse in the Qur'an which forbids entrance into a residence without the consent of its tenants. But, similar to western law, Islamic law allows for cases when individual rights must be subordinated to the rights of society.

Perhaps more significant in Bennabi's discussion on the rights of minorities is his discourse on democracy. The illustration he gives in the study relates to a Jewish woman whose house could not be taken under Caliph Omar's rule, even though a mosque was to be built on the same land. The reasoning was that the Jewish woman could not consider a mosque as part of the public domain; therefore, the Muslim authorities were left with no choice but to leave her house alongside the mosque.

Even more interesting, all through Bennabi's discourse is an unyielding rational interpretation of the Qur'an and of the Hadith. Such a course makes it possible for him to view Islam as a faith that exhibits all the attributes of a political democracy, where the principle of consultation not only exists but is also one that "provides the individual with respon- 
sibility in the constitution of power and all the guarantees against its abusive use." 18

Bennabi criticizes western democracies because, in his opinion, they do not embody social rights, since the individual can become a slave to powerful interests; he is also critical of the former eastern bloc because the socialist states conferred social rights to the citizens to the detriment of political liberty. Bennabi was convinced that Islam offers genuine democracy because it is a synthesis between political democracy and social democracy. He argues that the zakat (the giving of mandatory alms) is a good illustration of Islam's social legislation postulated by the Qur'an. The intercommunication that he said existed between rulers and ruled in the time of the first caliphs of Islam is evidence that a "democratic conscience molded Islam." ${ }^{19}$ Still, the true foundation of democracy remains human beings and the value conferred upon them by God. The intellectual influence of the Enlightenment on some of Bennabi's thought is here manifest, as confirmed by his references throughout the book to the writings of French philosophers.

Bennabi believed that the golden age of Islamic democracy was under the rule of the first caliphs. A regression took place, however, when power became absolute, but also when Islamic democratic thought vanished from the moral order in the behavior of Muslims. Islamic democratization ceased "when it lost its foundation in the psychology of the individual, as soon as the latter lost definitively the appreciation of his own worth and the value of others." ${ }^{20}$ From that time onward, Islamic civilization vanished because it no longer rested on the excellence of the individual. Bennabi felt that the recurrence of the democratic spirit had come into sight in some Islamic countries. However, he believed that the democratization process would only succeed when this new change has taken place within the individuals' own consciences so that they could elevate themselves above both the despot and the slave. He was convinced that "only Islam could undertake this reevaluation in the countries where social tradition has been shaped by the Qur'anic conception." 21

\section{Conclusion}

My objective has been to bring to the attention of scholars interested in Islamic thinking a small aspect of perhaps the greatest Islamic thinker Algeria has ever produced. It would be no exaggeration to say that Malek Bennabi is the only Algerian reflective thinker who has attempted to develop a systematic discourse on the relationship between Islam and democracy. His endeavor was to create a truly democratic psychology through a rational understanding of Islam. But, Bennabi was too much of a maverick, little known in his own society and harassed by an authoritarian regime. 
Without a doubt, he was the only Islamic thinker not only to have adopted in his discourse many aspects of western political democracy, but also to have proposed new ideas, inspired by Islamic values, to enrich democracy as a whole. Many Algerian Islamists, such as Mahfoud Nahnah, president of Hamas (Movement for the Islamic Society, founded in 1990), owe a great deal to Bennabi ${ }^{22}$ but never acknowledge their debt to him. It often seems as if Bennabi was ahead of his time, that his ideas were too intellectual and in direct contradiction with the populist, highly politicized discourse held by many Islamists in his day.

\section{Notes:}

1. Malek Bennabi, Le probleme des idées dans le monde musulman (Algiers: ElBay'yinate, 1990), 127. Bennabi had initially started writing the book in 1960 when he was in Egypt. However, he had abandoned his project until his friend, Dr. Ammar Talbi, convinced him to pursue it. He eventually completed the book in 1970 .

2. A biographical sketch of Malek Bennabi can be found in Aissa Khelladi, Les islamistes algériens face au pouvoir (Algiers: Editions Alfa, 1992), 37-44. Malek Bennabi's books have been - or are in the process of-being reprinted under the editorship of Nourredine Boukrouh, leader of the Parti pour le renouveau algerien (Algerian Renewal Party-PRA), founded in 1989.

3. See Khelladi, Les islamistes algériens, 91. Among Bennabi's works, which have yet to be carefully studied, one should refer to Le Phénomène coranique (Algiers: SEC, 1992) and Pour changer l'Algérie (Ouled Fayet, Tipaza: Société d'édition et de communication, 1989).

4. This section is summarized from Bennabi, Pour changer l'Algérie.

5. Malek Bennabi, La Démocratie en Islam (Alger: Mosquee de Beni Messous, n.d.), 10.

6. Ibid., 16-17.

7. On this notion, see Edward Shils, "The Virtue of Civil Society," Government and Opposition, 26, no. 1 (Winter 1991).

8. Bennabi, La Démocratie en Islam, 12.

9. Ibid., 15 .

10. Ibid., 17.

11. Ibid.

12. Ibid.

13. Ibid., 19.

14. Ibid., 20.

15. Ibid., 21-22.

16. Ibid., 24 .

17. Ibid., 29.

18. Ibid., 33 .

19. Ibid., 36 .

20. Ibid., 42.

21. Ibid.

22. Nourredine Boukrouh, “Comment j'ai connu Malek Bennabi," El Watan (Algiers), November 11-12, 1992. 